\title{
Landscape development in the safety assessment of a potential repository in Forsmark, Sweden
}

\author{
T. Lindborg ${ }^{1}$, L. Brydsten ${ }^{2}$, J.-O. Näslund ${ }^{1}$ and U. Kautsky ${ }^{1}$ \\ 1 Swedish Nuclear Fuel and Waste Management Co, Box 250, SE-101 24 Stockholm, \\ Sweden \\ 2 Umeå University, Department of Ecology and Environmental Science, 90187 Umeå, \\ Sweden
}

\begin{abstract}
One challenge in the analysis of far future radiological effects of a deep geological repository is to handle changes in time on ecosystems potentially affected. Under Swedish regulations, the time span that needs to be assessed is 100,000 yrs or more. This has historically been treated by using a reference biosphere that, in short, takes into account the total data range of the site properties that may change with different climates and sites. One problem with this strategy has always been to show that these reference biospheres have relevance for a specific site. To overcome this problem, SKB has adopted a strategy that uses site specific information together with scientific literature to build a narrative. This narrative describes the site development during a 100,000-yrs period (time frame of the present global glacial cycle). The information is used to compile a number of models that describe how the succession of abiotic and biotic features and their properties will develop at the site. The resulting Landscape Development Model is finally used in two ways: to tell the narrative of the site development based on scientific understanding and interdisciplinary consensus, and to populate the Radionuclide Model that is used to describe the effects of released radionuclides in a changing environment.
\end{abstract}

\section{INTRODUCTION}

The Swedish Nuclear Fuel and Waste Management Co (SKB) are performing a safety assessment (SRSite) of the long term safety of a planned repository for spent nuclear fuel in Sweden, Forsmark. As a part of the assessment, the effects on the biosphere are analysed. The biosphere assesment approach at SKB uses the development of the site as a basis for deriving input data to the models used to calculate potential doses to man and the environment for different future scenarios. This paper discusses the strategy, methodology and results from the modelling of the landscape development in the SR-Site safety assessment.

\subsection{Background}

To construct realistic descriptions and assumptions of future conditions at Forsmark, a good site understanding is needed. The past and present biosphere at Forsmark is well known and described in a number of SKB-reports, as well as in scientific articles. This knowledge is summarized and synthesised in $[1,2]$. Information from the site descriptions together with generic data, are used as baseline to build conceptual models describing process understanding, and discipline-specific models describing the future development of the Forsmark site.

During the site investigation phase that proceed the safety assessment, all the scientific disciplines used in site development and radionuclide modelling aimed at building site understanding. A conceptualisation of the present surface system at Forsmark was a preparatory task for the safety assessment [1]. A major task of this conceptualisation was to identify present ecosystems at the site and divide them into functional components. These entities were then described in terms of biotic and 


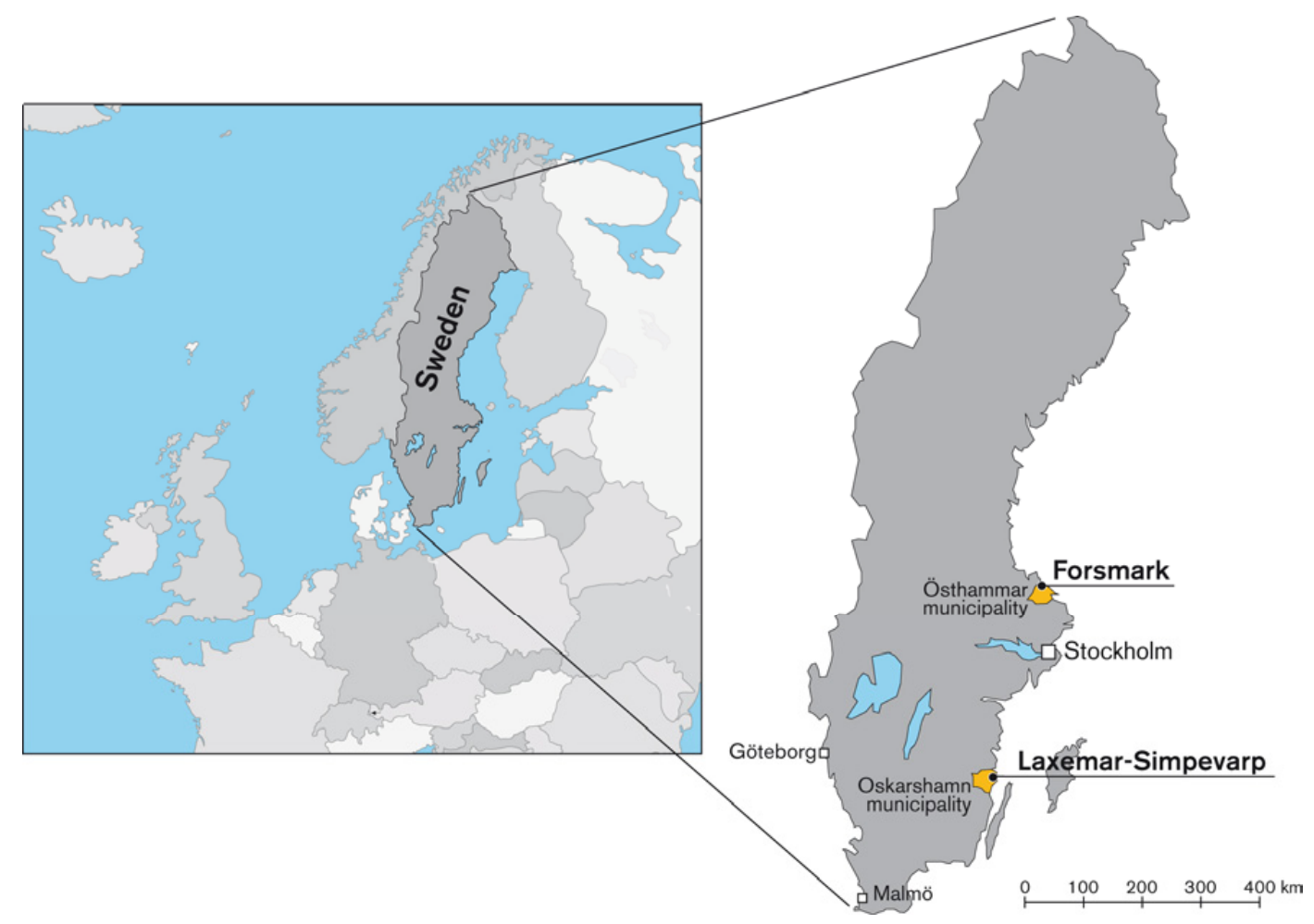

Figure 1. The Forsmark site location. Forsmark is situated $140 \mathrm{~km}$ north of Stockholm in Östhammar municipality. The Laxemar-Simpevarp area, where site investigations also were performed is seen approximately $300 \mathrm{~km}$ south of Stockholm.

abiotic features and properties. The ecosystems were described with a focus on ecosystem processes, and on transport and accumulation of matter, within and between ecosystems. Hydrological models and chemical information were used to describe mass balances for water and for a number of elements, both in individual ecosystems and at a landscape level.

In SR-Site, we used the current site information to develop descriptions of possible future development of Forsmark. One main driver for site development is climate change. As a main reference case for future climate in SR-Site, the last glacial cycle is used as an analogue [3]. In this analogue, the reference glacial cycle starts when the Weichselian ice retreats from Forsmark around 8800 BC and continues until c 120,000 AD when the cycle is completed. During the reference glacial cycle, a number of climate-driven conditions appear; from submerged conditions directly after the ice sheet has withdrawn, to recurrent temperate, periglacial and glacial domains [3].

\subsection{Site description}

The Forsmark area is situated at the shoreline of the Baltic Sea in northern Uppland, Sweden. Postglacial land uplift, in combination with the flat topography, implies fast shoreline displacement that has resulted in a very young terrestrial system that contains a number of newborn shallow lakes and wetlands. The lakes themselves are also of a specific type that is only found in northern Uppland. Shallow and with sediments rich in calcium, the lakes are unique in Sweden. Hydrological, the area also differs from the regional pattern. High water flows in the upper part of the bedrock are associated with a 


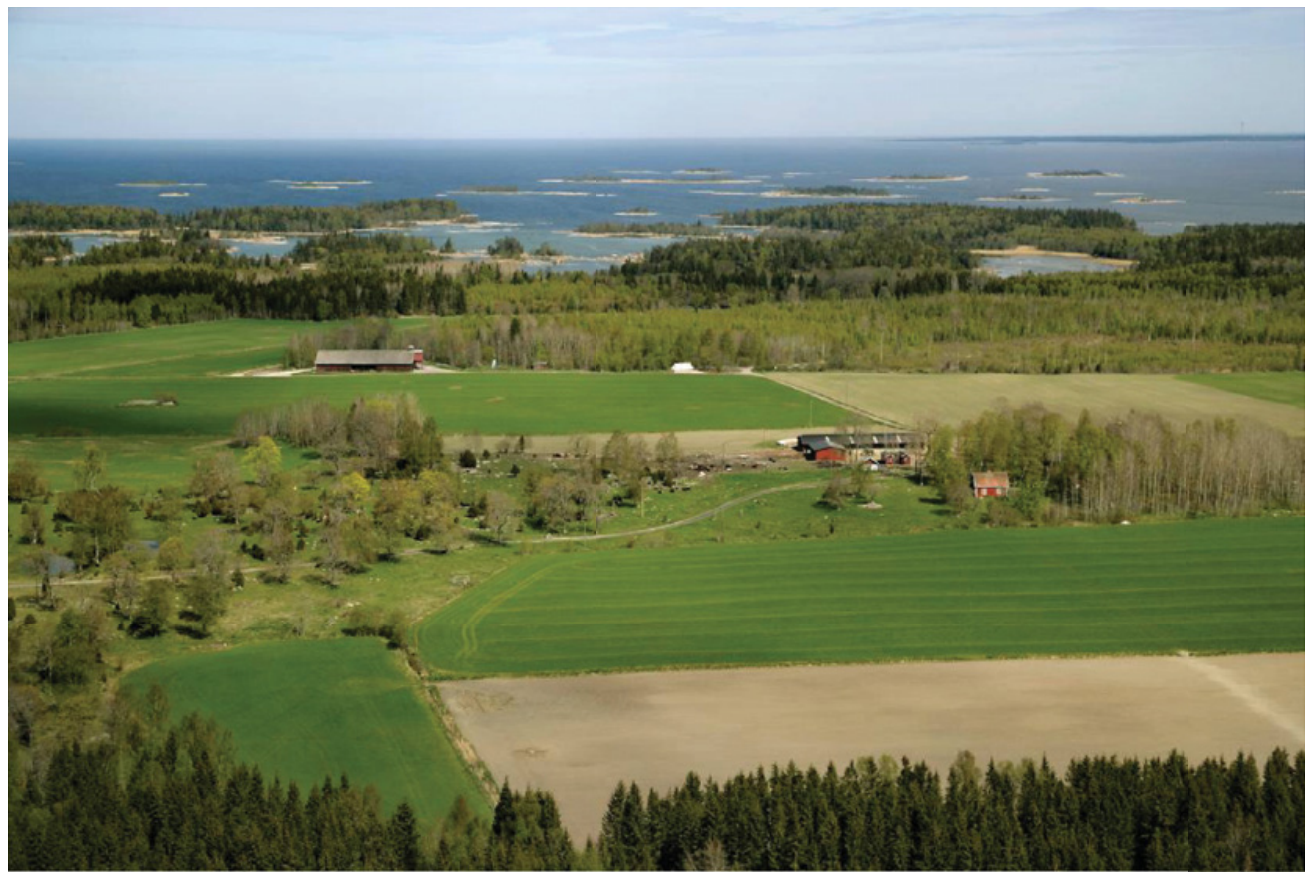

Figure 2. Arial photograph of Forsmark. The picture shows the agricultural areas in the eastern parts of the site that were below sea level 500 years ago. In the background the sea and the young archipelago that will constitute heights in the future landscape is seen.

complex network of gently dipping and sub-horizontal, open and partly open fractures in the upper part of the bedrock.

The latest deglaciation in Forsmark took place during the Preboreal climatic stage, c. 10,800 years ago $[3,4]$. Forsmark is situated below the highest coastline, and when the latest deglaciation took place, the area was covered by c. $150 \mathrm{~m}$ of water. The closest shore/land area at that time was situated c. $80 \mathrm{~km}$ to the west of Forsmark. The shoreline displacement has strongly affected landscape development and still causes a continuous and relatively predictable change in the abiotic and biotic environment, e.g. in water and nutrient availability. The first parts of Forsmark emerged from the sea around 500 BC. Thus, the post-glacial development of the surface system is determined mainly by the development of the Baltic basin and by the shoreline displacement [2].

The study area is characterized by a small-scale topography with limited variations in altitude and is almost entirely located below 20 m.a.s.l. Till is the dominant QD, whereas granite is the dominant rock type. The annual precipitation and runoff are 560 and $150 \mathrm{~mm}$, respectively. The largest lakes in the area are Lake Fiskarfjärden, Lake Bolundsfjärden and Lake Eckarfjärden. The lakes are small (the largest lake is c. $0.6 \mathrm{~km} 2$ ) and shallow, with mean and maximum depths ranging from approximately 0.1 to $1 \mathrm{~m}$ and 0.4 to $2 \mathrm{~m}$, respectively. Sea water flows into the most low-lying lakes during events giving rise to very high sea levels. Wetlands are frequent and cover 25 to $35 \%$ of some of the delineated sub-catchments.

\section{METHODS}

The future development of the Forsmark landscape is one of the main features in SR-Site and constitutes a fundamental input to the final radionuclide modelling. The general idea is to use the defined long term 


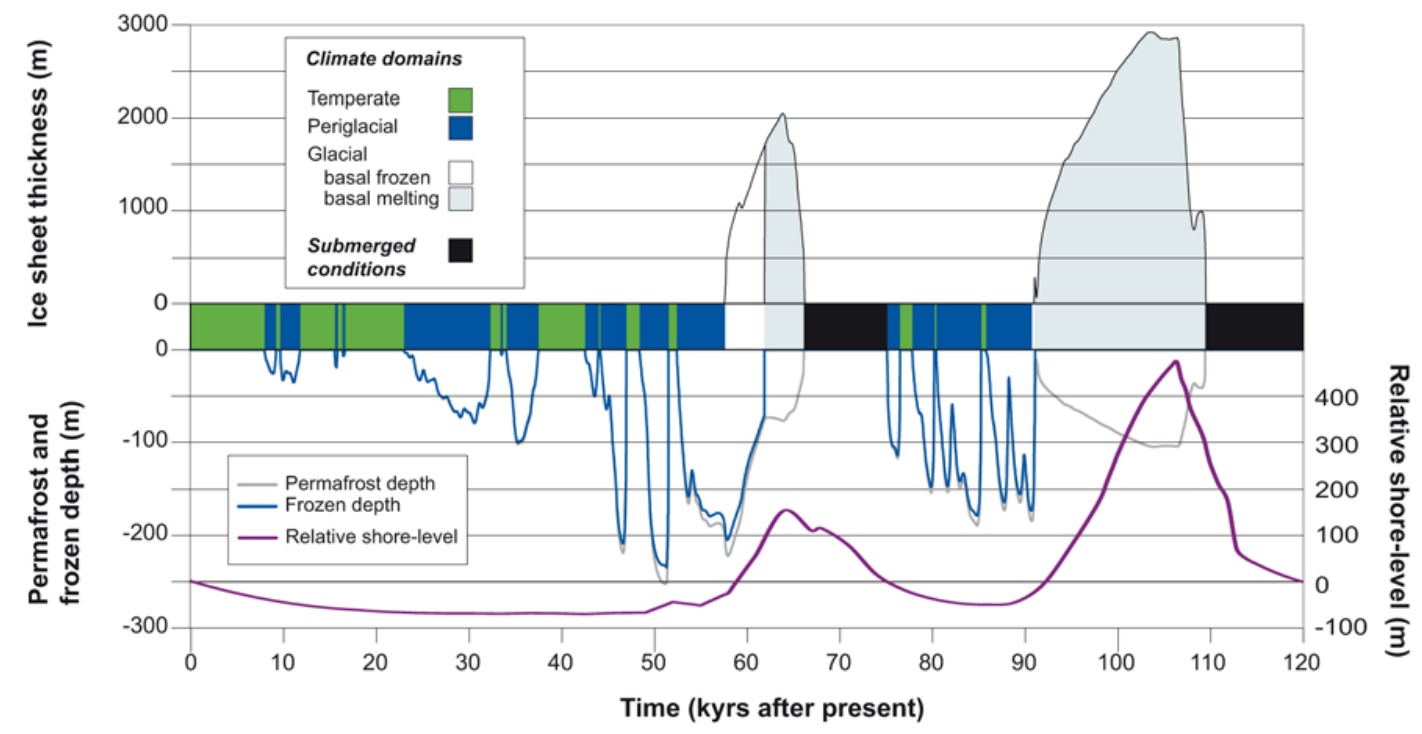

Figure 3. The development of climate related processes according to the SR-Site reference glacial cycle. Figure from [5].

processes that affect the landscape and apply them on different domains. The discipline specific models are then combined to a final landscape development model. Main input to this work is present geometry, shoreline displacement, regolith and sedimentation rates, ingrowth of vegetation, possible land use, climate and hydrology.

The biosphere programme in SR-Site has chosen to describe and to perform dose modelling based on the two climate cases that constitute the SR-Site main scenario [3], i.e. the reference glacial cycle and the global warming climate case. The reference glacial cycle comprise all three climate domains as well as submerged conditions. The global warming climate case describes a climate development influenced by anthropogenic burning of fossil fuel. Periods of a temperate climate domain correspond to $26 \%$ and periglacial climate domain occupies $34 \%$ of the total time of the reference glacial cycle (120,000 years), whereas periods with glacial climate domain occupy $24 \%$ and periods with submerged conditions occupy $16 \%$ of the reference glacial cycle,

The climate succession bar in Figure 3 shows that the Forsmark site is dominated by temperate climate conditions for the first 25,000 years, although shorter periods of periglacial climate domain occur around 10,000 year after present. Subsequently, up to the first period of glacial climate domain, temperate conditions are gradually replaced by periglacial conditions. The ice-free interstadial period around $80,000-90,000$ years after present is dominated by periglacial climate domains.

The topography has an effect on many processes in the landscape such as the lake formation, the groundwater hydrology, the surface hydrology, the sediment dynamics in the sea and therefore also the dynamics of radionuclides. The topography of a landscape is often described with a digital elevation model (DEM) and this has been done for Forsmark. The DEM is a required input to most models generated within the SR-Site project. A high accuracy of the DEM is therefore important for the accuracy of the whole project.

The pattern of elevation is constantly changing throughout the glacial - interglacial cycle. Many processes control these changes such as glacial isostatic adjustment (GIA) and transport of sediments. The changes in DEM due to sediment dynamics are discussed later in this report. GIA is the response of the solid earth to mass redistribution during a glacial cycle [7]. During glacial periods, the ice sheets at higher latitudes growth and the relative sea level falls and the opposite occur during 
interglacial periods; the ice sheets melt and the relative sea level rises. The movement of water from the sea to the ice sheets acts as a load on the lithosphere under the ice and a rebounding under the sea. Thus, GIA is the deformation that takes place due to melting or growing of ice sheets. The relative sea level is defined as the height of the contact between the ocean surface and land. A rise in the relative sea level can be caused by an increased ocean surface height or a decreased height of the land, for example due to ice loading.

The accumulation of sediment and peat as well as erosion of sediment on the sea floor will continue in the future. The distribution of QD in the Forsmark area will consequently change throughout the present interglacial. Furthermore, the proportional distribution of QD in the terrestrial part of the Forsmark area will change as new land is uplifted. It is of course not possible to predict the future distribution of QD in detail. It is, however, obvious that the proportion of terrestrial areas with clay will increase as the present sea floor is uplifted. In the present terrestrial area the proportion of peat will increase significantly as the shallow lakes are infilled and the low-lying wetlands are covered by a layer of peat. New lakes will form when the present sea floor is uplifted. Also, these lakes will successively be filled with gyttja and peat. The proportion of land suitable for agriculture will increase significantly in the future as the clay sediment at the sea floor is uplifted.

A coupled model for regolith-lake development has been constructed and was applied to the Forsmark area. The model predicts the distribution of Quaternary deposits during an interglacial. The regolith-lake model is divided into two modules: a marine module that predicts the sediment dynamics caused by wind waves and a lake module that predicts the lake infill processes. The marine module starts at the time when the area has recently been deglaciated and all Quaternary deposits are of glacial origin (surface geology, stratigraphy, and thickness around $8800 \mathrm{BC}$ ). These conditions are generated using the regolith depth model [7]. This model is in raster format with seven layers where each layer is presented as a digital elevation model for the upper surface of that particular layer. The uppermost three layers in the regolith depth model are formed during the postglacial period, so the bottom four layers represent the stratigraphy as it existed shortly after the deglaciation.

Finally, when putting all these models described above together, we have a tool to describe the whole system as it develops during a reference glacial cycle. This merging of models is done in a geographical information system (GIS) and a map of the future landscape can be displayed. This map is dynamic due to the underlying process models and can show the landscape status at any specific time step needed to build a description of the general landscape succession.

\section{RESULTS}

In the reference glacial cycle, Forsmark will exhibit a temperate climate domain during the initial 25,000 years, even though this domain will be interrupted with shorter periglacial climate domains. During a temperate climate domain, the spatial distribution of ecosystems in the area will change due to the shoreline displacement, decreasing the initial extensive marine area (the submerged marine stage, in average a 150-200 $\mathrm{m}$ deep offshore area) and extending the areas for limnic and terrestrial ecosystems as a result of the regressive shoreline. In Figure 4, present conditions (2000 AD) and the predicted landscape in $5000 \mathrm{AD}$ are presented to illustrate the changed distribution of the ecosystems in the area. In the present landscape of Forsmark the shoreline displacement has over long periods continuously created inshore bays, lakes and new land areas. The subsequent succession of these emerging areas follows different trajectories depending on local factors such as wave exposure during the marine shore stage, slope and surrounding topography. Succession is a directional change of ecosystem structure and functioning, which may occur over time scales from decades to millennia.

The model has distributed information in grid cells with a scale of a few tens of metres for both abiotic and biotic properties, and for the time scales needed to describe the far future. However, the landscape development model is not a prediction of what is to come, but a realistic description of a relevant future. 

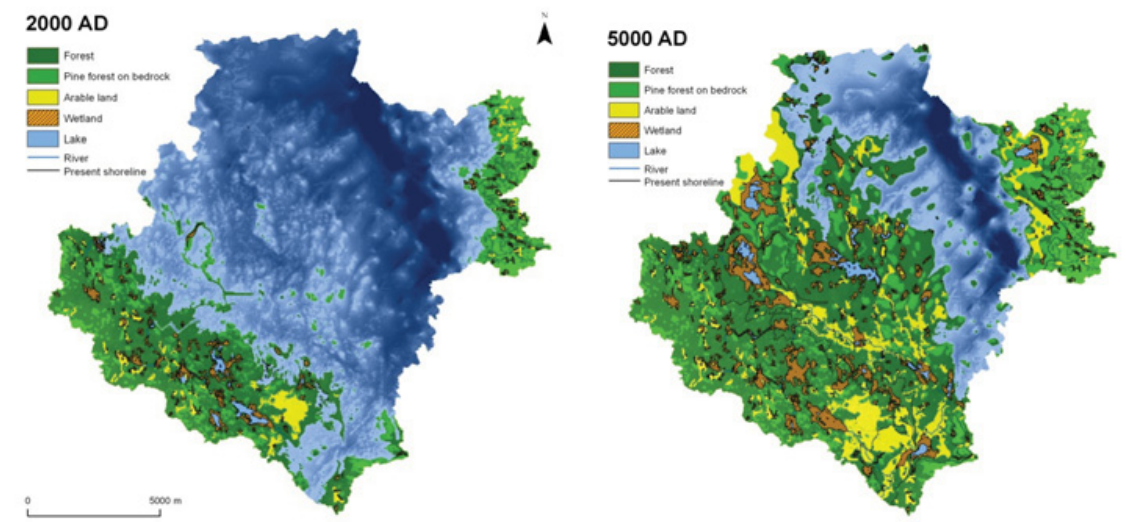

Figure 4. The time steps $2000 \mathrm{AD}$ (present time) and $5000 \mathrm{AD}$ of the landscape development in the Forsmark model area. Modified after [8].

\section{DISCUSSION}

Long-term landscape development in the Forsmark area is dependent on two main, and partly interdependent factors; climate variations and shoreline displacement. These two factors in combination strongly affect a number of processes, which in turn determine the development of ecosystems. Some examples of such processes are erosion and sedimentation, groundwater recharge and discharge, soil formation, primary production and decomposition of organic matter. Climate variations will directly change the conditions for ecosystem formation, e.g. the formation of wetland complexes, and cause north- and southward migration of species and ecological communities. Changes of species distributions have the potential of affecting whole ecosystems through the emergence or disappearance of species that may have a key function in the ecosystem. Examples of such species are the megaherbivores that are thought to have kept the forests fairly open during long periods after the latest deglaciation, or a predator that directly may alter the food web and thereby the whole ecosystem. The second important factor for long-term landscape development, shoreline displacement, is a secondary effect of climate variations. It is caused by the interaction between glacially induced isostatic depression/recovery on the one hand, and eustatic sea-level variations on the other. Periodically, shoreline displacement has strongly affected the Forsmark area, both before and after the latest deglaciation. Accordingly, the area has repeatedly been situated below sea level for long periods [2].

The final landscape development model is, as described above, a synthesis of all available information on abiotic and biotic properties, processes and long-term succession. This means that the uncertainties in each of the underlying models are to be taken into account when discussing potential uncertainties in the landscape development model as a whole. However, the future development of the Forsmark landscape is not to be seen as a distinct prediction, but more as a relevant example on how Forsmark may develop during the present interglacial period. We argue that this example, built on extensive site data and process understanding, also is relevant for all future interglacials to come. We also believe that this dynamic approach, with its final simulated succession model, gives us a useful tool to explain the results, not only to the initiated reader but to the public and non professionals searching for information on how site-specific data used in risk calculations are extracted and how the site understanding is implemented in the dose calculations.

\section{References}

[1] Lindborg T (ed), 2008. Surface system Forsmark. Site descriptive modelling, SDMSite Forsmark. SKB R-08-11, Svensk Kärnbränslehantering AB. 
[2] Söderbäck B (ed), 2008. Geological evolution, palaeoclimate and historical development of the Forsmark and Laxemar-Simpevarp areas. Site descriptive modelling, SDM-Site. SKB R-08-19, Svensk Kärnbränslehantering AB.

[3] Persson C, 1992. The latest ice recession and till deposits in northern Uppland, eastern central Sweden. Geological survey of Sweden, Ser. Ca 81, pp 217-224.

[4] Strömberg B, 1989. Late Weichselian deglaciation and clay varve chronology in eastcentral Sweden. Sveriges Geologiska Undersökning, Series Ca 73, 70 pp.

[5] Climate and climate-related issues for the safety assessment SR-Site. SKB TR-10-49, Svensk Kärnbränslehantering AB.

[6] Whitehouse P, 2009. Glacial isostatic adjustment and sea-level change. State of the art report. SKB TR-09-11, Svensk Kärnbränslehantering AB.

[7] Hedenström A, Sohlenius G, Strömgren M, Brydsten L, Nyman H, 2008. Depth and stratigraphy of regolith at Forsmark. Site descriptive modelling, SDM-Site Forsmark. SKB R-08-07, Svensk Kärnbränslehantering $\mathrm{AB}$.

[8] Lindborg T (ed), 2010. Landscape Forsmark - data, methodology and results for SR-Site. SKB TR-10-05, Svensk Kärnbränslehantering AB. 